\title{
Manejo de información en el sistema literario
}

\author{
Domingo Alberto Vital DíaZ \\ Investigador del Centro de Estudios Literarios del \\ Instituto de Investigaciones Filológicas de la UNAM \\ E-mail:vital@ servidor.unam.mx
}

\begin{abstract}
RESUMEN
Se analizan los elementos coincidentes y divergentes entre oralidad y escritura cibernética, a fin de conocer la situación que se da en el flujo de información, en cada uno de estos canales. A partir de ello, se desprende cómo la elaboración de fuentes como el Diciananio deEscitares Mexicanos (Sigo XX) del Instituto de Investigaciones Filológicas de la UNAM, representa una buena alternativa para coadyuvar la problemática que se observa.
\end{abstract}

\begin{abstract}
Coincident and diverging elements between oral speech and cybernetics writing are analyzed to approach the situation given in the information flow within each of these channels. From there it can be inferred that the preparation of sources suchs as the Dicionario de Escritares Mexicanos, Sigo XX (Dictionary of Mexican Writers, XX th Century) by the Instituto de Investigaciones Filológicas (Philological Research Institute) of UNAM (National Autonomous University of Mexico), are a good alternative for helping to solve the observed problems.
\end{abstract}

Е flujo de información en la vida literaria se ha vuelto tan intenso que la definición misma, en tanto sistema, depende ya de la descripción de las redes por donde transitan los datos que conforman a la vez un conjunto de corparay un canon, esto es, una serie de textos y un intento por jerarquizarlos conforme a valores estéticos, a éxitos en el mercado entre la crítica especializada y al cumplimiento o incumplimiento de funciones sociales decisivas.

De hecho, como ya lo advirtió Walter Mignolo, las nociones de conpus y de canon literarios se relacionan con términos de tensión: podríamos definir, aquí, la primera como la producción y reproducción horizontal y más bien indiferenciada de textos y paratextos, así como el intento de recuperación y fijación de los mismos por el valor que tienen ya de suyo, sea estético o puramente documental 0 histórico; definiríamos la segunda como la jerarquización, la verticalización de la

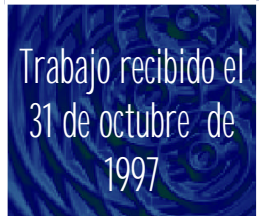


suma de textos y datos producidos, lo cual conlleva una selección, es decir, una discriminación que implica exclusión de grandes cantidades de información.

Una de las actividades fundamentales hoy-cuando se vive en medio de una exuberancia informativa, cuando existen millones de fuentes a las cuales se puede tener acceso instantáneo desde múltiples lugares del mundo- consiste, justo, en la verticalización discriminadora de todos los datos de un coms. Ello otorga al resumen, como género discursivo, una importancia de la que careció en otras épocas. En el sistema literario, abundan los espacios donde se procesa la producción para abreviarla, codificarla y trasladarla a una alta cantidad de receptores: el periodismo cultural (impreso y electrónico), los manuales históricos, los planes de estudio, los ensayos panorámicos y las antologías canonizadoras son algunos de esos ámbitos, cuya creciente importancia se percibe en el prestigio (o poder simbólico) alcanzado por las personas encargadas de ejercerlos o ejecutarlos.

El carácter estratégico del resumen se cifra en dos factores: 1) la relevancia del sitio desde el cual se remite y 2) el impacto que produce según el tamaño y la significación del público al cual llega. D e hecho, si se ha vuelto un axioma la experiencia de que el manejo de la información es siempre político, en el sistema literario, ese manejo alcanza su presión máxima cuando aparecen resúmenes de los tipos arriba mencionados, pues en ellos se juega el destino de numerosos textos y escritores: para unos y otros, la inclusión/ exclusión en/ de dichos espacios representa no sólo un (re)(des)conocimiento, sino la posibilidad misma de seguir formando parte de un sistema altamente especializado, jerarquizado y, hasta cierto punto, impersonal.

Ahora bien, frente a los espacios de canonización sinóptica crecen las prácticas que multiplican los copara y los flujos de información sin que se presenten por fuerza las típicas fijaciones paralizantes de los cánones impresos: dos vertientes - en muchos aspectos opuestas; en otros, afines- frenan la tendencia a la canonización absolutista de la letra impresa; me refiero a la oralidad y a la escritura cibernética.

La oralidad proviene, tradicionalmente, de sectores marginales, con escaso 0 nulo acceso a los poderes de la escritura impresa; la literatura cibernética, por el contrario, es un rizoma que usa tecnología de punta y trata de resolver las limitaciones de lo impreso, como la ya señalada fijación canonizadora. A mbas, oralidad y electrónica, son susceptibles de metaforizarse como un terreno movedizo, en continua expansión y contracción, donde las nociones de <autor> y <texto>-fundamentales para la letra impresa- se vuelven problemáticas. Ello 
comporta asimismo un cuestionamiento a dos productos capitales de la modernidad, dado que en ésta la determinación del < texto > y del <autor > forman parte esencial de la multiplicación y reproducción de los saberes, de la universalización de los postulados básicos y de la responsabilidad del individuo acerca de todo cuanto enuncia. La oralidad tiende a ser no moderna o amoderna -como se prueba en prácticas textuales de grupos indígenas-; la cibernética puede ser posmoderna si en verdad supera esas nociones y se sitúa en el provocativo territorio de un trabajo colectivo y horizontal donde se organicen y enriquezcan voces procedentes de los más diversos cortes sociológicos.

Ahora bien, las prácticas orales y la cibernética podrían superar una de las consecuencias de la necesidad de resumir toda la información generada por el sistema literario: la conversión de meros datos cosificados de todo aquello que - como conjunto de discursos- entraña pulsiones y es campo de batalla entre valores e intereses, espacio de marcada tensión entre diversas imágenes del mundo o de lo inmediato, sitio donde se han discutido y dirimido los grandes problemas de la existencia.

Ahora bien, las prácticas cibernéticas ya incluyen revistas y antologías, es decir, dos de las formas habituales de la difusión y la canonización de compaliterarios. Una variante decisiva respecto a los usos impresos, consiste, justamente, en la posibilidad de que unas y otras se ramifiquen en el tiempo y en el espacio. De hecho, las antologías cibernéticas se hallan en condiciones de cumplir una función difusora y una canonizadora, sin que una y otra recaigan en las fijaciones que tantas polémicas y frustraciones han causado desde las antologías en papel. D e ese modo, sería posible que el enorme poder alcanzado por los intermediarios en el sistema - equivalente al del transportista, muy superior al del campesino- disminuyera en favor del auténtico productor, a menos que siguiera siendo cierta aquella célebre frase de hace unas décadas - "El medio es el mensaje" - , y las redes electrónicas adquirieran tal dinámica que acabaran devorando nuevamente a los creadores.

Como un vívido ejemplo de las tensiones entre el copusy el canon - en tanto que dos instancias distintas de organización, preservación y difusión de los datos generados en el sistema literario-, recordemos aquí el enorme éxito alcanzado por El canon ocidantal (1994), de Harold Bloom, ambiciosísimo volumen que intenta resumir en listas, las principales obras del siglo XX. Bloom coloca en el centro de ese canon la obra de William Shakespeare y olvida, al enmarcar la producción latinoamericana, la obra de Juan Rulfo, que es entre nosotros el equivalente de Shakespeare. El éxito del volumen habla claramente de la urgencia 
- entre el público de muchos lugares- de orientarse en medio de una vastísima producción mundial, absolutamente inabarcable, incluso, para algún lector de dimensiones fáusticas; una ausencia como la de Rulfo habla, en cambio, de la precariedad del proyecto de Bloom, atravesado por limitaciones de tiempo y espacio $\mathrm{y}$, sobre todo, por presiones políticas, dado que Bloom ha establecido contactos con México y muestra conocer muy bien a otros autores importantes del continente, de manera que la omisión de una señal tan visible en el tablero latinoamericano como Rulfo, sólo puede atribuirse a causas extraliterarias.

En resumen, uno de los conflictos latentes hoy en el sistema literario consiste en que no es posible prescindir de la función canonizadora, la cual discrimina y jerarquiza la abundantísima información generada, ni parece viable cumplir esa función como se hizo durante siglos, ya que la misma exuberancia de datos y la presencia de tensiones políticas en el sistema limitan radicalmente las tareas del individuo encargado de la canonización.

Una manera de solucionar estas presiones consiste en elaborar diccionarios objetivos, donde se registre sistemáticamente toda la información posible. Conforme a ese criterio, el Centro de Estudios Literarios del Instituto de Investigaciones Filológicas produce desde hace años el Dicionario deEscritores Mexicanos. SigoXX, fuente confiable e indispensable de consulta para todos los especialistas. Asimismo, la conversión del diccionario en un disco compacto duplica sus posibilidades de uso.

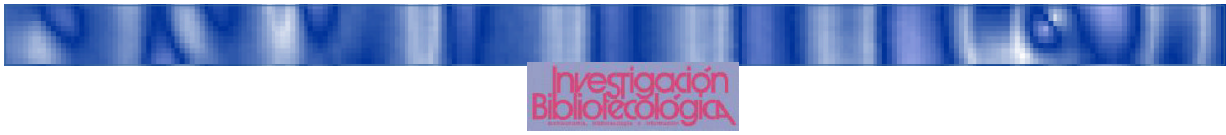

